This is a self-archived version of an original article. This version may differ from the original in pagination and typographic details.

Author(s): Lähdesmäki, Tuuli

Title: Founding myths of European Union Europe and the workings of power in the European Union heritage and history initiatives

Year: 2019

Version: Accepted version (Final draft)

Copyright: (C) The Author(s) 2018

Rights: In Copyright

Rights url: http://rightsstatements.org/page/InC/1.0/?language=en

Please cite the original version:

Lähdesmäki, T. (2019). Founding myths of European Union Europe and the workings of power in the European Union heritage and history initiatives. European Journal of Cultural Studies, 22(56), 781-798. https://doi.org/10.1177/1367549418755921 
FINAL DRAFT. Lähdesmäki, Tuuli (2019): Founding myths of EU Europe and the workings of power in the EU heritage and history initiatives. European Journal of Cultural Studies 22:56, 781-798. DOI: 10.1177/1367549418755921.

\title{
Founding myths of EU Europe and the workings of power in the EU heritage and history initiatives
}

\begin{abstract}
Along with the European Union's (EU) increased interest in a common European culture and past, narration as a means to create and communicate about them have gained new momentum. By applying the Discourse-Mythological Approach, I explore how the EU narrates the story of the origins of EU Europe in two recent EU heritage/history initiatives. The analysis brought out three storylines in the mythmaking of EU Europe. While the first storyline emphasizes temporal continuity, shared cultural roots, and preservation and transmission of a common legacy, the second one focuses on the idea of a break and a rebirth of a civic/political community. The third storyline highlighting founding figures and key heroes functions as a mediator between these two narratives. The founding myths seeks to justify the political aims of the EU, i.e., strengthening European unification and multilevel integration, and present these aims as choiceless and morally and ethically legitimated.
\end{abstract}

Keywords: founding myth, Europe, European Union, narration, politics, power

The EU's need for a new narrative 
During the past two decades, the European Union (EU) has been increasingly interested in a particular European amalgam of knowledge, attitudes, and values, common European cultural roots and heritage, and a shared European memory that transcends national differences in interpreting the past in Europe. The EU's interest in its own and Europe's past—pasts that are commonly paralleled in EU policy rhetoric_-is manifested in both EU policy discourse and the recent EU's history and heritage initiatives that seek to put the policy into practice. This EU's recent 'move to history' (Littoz-Monnet, 2012; Prutsch, 2013) is at the same time a highly future-orientated project: narrations of the past function as building blocks through which the EU seeks to create a particular image and understanding of itself and its citizens.

Although the EU and its predecessors have been interested in promoting and utilizing the idea of shared cultural elements and a common European identity since the 1970s, the past two decades can be comprehended as an intensive moment in the making of EU Europe-i.e., Europe as a polity that has both political and non-political cultural bases. Ringmar (1996) has called this kind of intensity a 'formative moment'. With this concept he refers to 'a time when the very definition of the meaningful is up for grabs; when old metaphors are replaced by new ones; when new stories are told about these metaphors, new identities established and new social practices initiated' (Ringmar, 1996: 85). Formative moments are periods when meanings are negotiated, contested, and fought over by means of rhetoric and propaganda. For Ringmar (1996: 85), such moments are also characterized by symbolic hyper-inflation; they are periods when 'new emblems, flags, dress codes, songs, fetes and rituals are continuously invented'.

Several scholars have explored post-WWII Europe-and its transforming geopolitics after the Cold War in particular — as a formative moment for different kinds of identity projects (e.g., Mi-Kyung and Robertson, 2002; Horelt and Renner, 2008; Bottici, 2014; Kaasik-Krogerus, 
2016). The geopolitical shifts in Europe and the mammoth project of EU enlargement as its consequence have been comprehended as a formative moment for the creation of the EU's own symbolism of unity (Scott 2002). Along with the enlargement and integration processes, the EU has produced diverse symbolic devices ranging from common emblems to rituals fostering the idea of unity in Europe, but also 'an ideational hyper-inflation' of meanings, as Scott (2002: 152) claims. Indeed, the EU has proclaimed various cultural, social, and societal virtues and values as defining elements of 'Europeanness' (Scott, 2002; Lähdesmäki, 2016) and is actively creating a story of EU Europe by inventing new and reinterpreting old meanings and metaphors.

Formative moments enable creation and promotion of narratives about 'who we are'. Ringmar (1996: 76) has conceptualized these narratives as 'constitutive stories' that create a presence for ourselves in both space and time. Constitutive stories articulate our physical location and explain our temporal existence in the world. In addition, constitutive stories can be used in making a claim to legitimacy. As Ringmar (1996: 78) notes, constitutive stories do not only produce meanings but also confer rights to exist in space and time; by telling the story of how the past came to produce the present, the narrator is able to back up his/her claim on power. Several studies in political science (e.g., Browning, 2008; Campbell, 1992) frame the very process of narrating a constitutive story that differentiates the (national) self from others as a core aspect of foreign policy. However, constitutive stories also have a crucial role in domestic policy when those in power seek to strengthen unity within a polity or redefine the bases of unity. In the EU, narration of a constitutive story is indeed an essential aspect of the EU's domestic policy. 
Along with the EU's increased interest in a shared culture, past, and identity in Europe, stories and narration as a means to create, mediate, and communicate about them have gained new momentum. The meanings of the EU and Europe have been recently rethought and re-narrated in various EU projects and initiatives seeking to offer 'a new narrative for Europe', as the name of the project launched by the European Commission in 2013 suggests. The EU's need for a narrative that would increase unity in Europe and promote acceptance of European integration has recently become even more urgent due to the severe political, economic, and humanitarian crises Europe has faced.

In this article, I explore a constitutive story of EU Europe by focusing on a particular mode of it: a story of the origins of EU Europe. I approach these stories as founding myths since they utilize various elements common in narrative structures of myths and workings of power related to mythmaking. I examine the founding myths of EU Europe through two EU heritage/history initiatives by analyzing how these initiatives tell the story of the emergence of EU Europe. The main questions of the article are: What kinds of founding myths of EU Europe do the EU heritage/history initiatives construct? How and why do these founding myths utilize the interplay between the past and present, historicity and temporal continuity, and an appeal to ethics and morality? How do these myths participate in the workings of power?

\section{Case initiatives, data, methods, and the theoretical approach}

The empirical analysis focuses on two key heritage/history initiatives of the EU's core administrative bodies-the European Parliament and the European Commission. Parlamentarium, the visitors' center of the European Parliament opened in the administrative 
block of the Parliament in Brussels in 2011, displays the 'official' story of EU Europe. The center is spread over three floors and includes exhibition spaces divided into six permanent and one temporary exhibition halls. The permanent exhibition in Parlamentarium starts from the 'History Area', where visitors are able to 'learn about Europe's long and often troubled history', 'find out about the EU's early visionaries', and 'track 50 years of European integration', as the Visitor's Guide of Parlamentarium claims (EP, 2016). The European Heritage Label (EHL) is the most recent heritage initiative of the European Commission. It was launched as a flagship heritage initiative and an official EU action in 2011. The action seeks to attain various objectives, such as 'stressing the symbolic value and raising the profile of sites which have played a significant role in the history and culture of Europe and/or the building of the Union', as one of the core objectives is described in the decision on the action (EP and CoEU, 2011: 3). In this initiative, the Commission awards sites with the European Heritage Label based on their applications in which the applicants have to argue 'the European significance' of the site. The first official labels were given in 2014 , and since then 29 sites have been awarded.

Both initiatives explicitly bring to the fore the idea of 'origin' - the idea that EU Europe has its roots and a starting point in some particular places and incidents to which the present day EU Europe can be traced. The slogan of the EHL, 'Europe starts here!', suggests that the awarded sites can be perceived as a start to EU Europe. At the same time, the present tense of the slogan suggests that the initiative itself is a start to EU Europe as a cultural project. The exhibition rooms in the 'History Area' of Parlamentarium are named 'Visions' and 'Beginnings', indicating the aim of the exhibition narrative: to tell the story of the start of EU Europe. This aim is underlined in the text reflected on the wall in the beginning of the Visions 
hall: 'It began with a vision: European economic and political cooperation as a way of avoiding conflict and ensuring peace.'

These two recent EU initiatives enable examination of how the key EU administrative bodies tell the constitutive story of EU Europe and what kinds of ideological attempts are included in it. The data from the EHL consist of selection reports produced by the expert panel, whose 13 members have been appointed by the European Parliament, the Council of the European Union, the European Commission, and the Committee of the Regions. The selection reports, which emphasize the criteria of the action in the evaluation of the candidate sites' 'European significance', are published by the Commission and represent the stand adopted by it. The data from the 'History Area' in Parlamentarium consist of texts, images, and transcribed information in portable media guides available in the exhibition. Parlamentarium represents the stand of the European Parliament: the launch of the visitors' center was based on the Parliament's decision, the focus of the exhibition is on the Parliament, and the explicit narrator of the exhibition narrative is the Parliament itself. The curators of the exhibition are not introduced in Parlamentarium.

The data were analyzed using the Discourse-Mythological Approach (DMA) developed by Kelsey $(2014 ; 2015 ; 2016)$ by combining myth theory with tools and frameworks of critical discourse analysis. From the broad field of discourse studies, DMA utilizes two interconnected theoretical orientations in particular: Wodak's discourse-historical approach and Faiclough's model for exploring and explaining the historical and social contexts of language and power relations (Kelsey, 2016: 4). The key interest and attempt in Wodak's (2008: 9) discoursehistorical analysis is to trace the intertextual history of phrases and arguments used in political discussions by integrating diverse background information in analyzing and interpreting the 
different layers of a text. This kind of focus of discourse analysis is useful in the examination of myths, as it enables connection of discursive traits from the past with representations in the present (Kelsey, 2011: 54), and thereby perception of the development of meanings and ideological implications of words, phrases, and stories in both diachronic and synchronic contexts (Kelsey, 2016: 4). The analysis model in DMA stems from Fairclough (1992; 1995), who has identified three layers of a text on which also the analysis itself focuses. In this model, the investigation combines textual analysis with analysis of discursive and sociocultural practices.

The critical emphasis of discourse analysis relies on a functionalist perspective of communication and thus directs one to analyze the intentionality and performativity of language use. Respectively, DMA focuses on analysis of the ideological role of linguistic elements in texts and their relation to power (Kelsey, 2015). As discourse studies stem from the idea of coexistence of different discourses that form hierarchical structures in relation to each other, similarly DMA is concerned with the coexistence of several myths that compete against one another in ideological battlegrounds of political storytelling (Kelsey, 2014; 2012; Flood, 2002). Following DMA, this article examines how the founding myths of EU Europe are constructed and expressed in a discursive form by using theoretical and methodological tools that critical discourse analysis offers.

The concept of myth has been defined in different ways in scholarly discussions. In anthropological traditions, myths refer to sacred, traditional tales (Leach, 1970: 54-55), while in cultural semiotics myths have been approached through their performativity and implications-myths naturalize certain (historical) stories and ideologies included in them (Barthes 1993). In scholarly use, myths do not include similar pejorative meanings—such as 
false history, distortion, or delusion—as they often do in everyday use (Leach, 1970; Flood, 2002; Whelan and O'Gorman, 2007). Instead, myths are seen as having unquestioned validity within the belief system of social groups that cherish them (Flood, 2002). Even though myths are not lies, they cannot be defined as truths, either. It is the abolition of complexity that characterizes myths and gives them their ability to provide clarity to those who believe in the social ideals myths represent (Kelsey, 2016: 2). At the same time, as Kelsey (2011: 53-54) notes, 'a myth reaches its most misleading and effective form when it comforts and escapes scrutiny'. Here also lies the power of myths: they are simplifying processes that function ideologically in the messages they deliver (Barthes, 1993: 143; Kelsey, 2015: 4); myths celebrate dominant beliefs, values, and moral norms and codes (Kelsey, 2011: 51; Lule, 2001: 12; Phillips, 2011); myths confirm the social ideals of the storyteller (Kelsey, 2016: 15); myths degrade and demean other beliefs that do not align with those of the storyteller (Lule, 2001: 184); myths present univocal stories of contradictory human history (Bell, 2003: 75); and myths legitimize the meanings of things in a way that transcends any grounds for debate or questioning (Kelsey, 2011: 51; Barthes, 1993).

Drawing from the power, performativity, and functionality of myths, scholars have perceived them as 'social narratives' and 'societal stories' that offer exemplary models for social life (Lule, 2001). Indeed, storytelling, remembering the past, and narrating history are social practices that are also easily politicized (Kelsey, 2015: 3) and actively used in the realm of politics to create political myths (Bottici 2007). As Wodak (2009: 15) notes, the way we deal with the past is part of the politics of dealing with the past. Historical narratives and historical contexts that these narratives bring to the fore, need, thus, to be understood as 'the outcome of a social process whereby past events that are regarded as worthy vehicles for moral concepts are selected and made the objects of remembrance and commemoration' (Wodak, 2009: 15). 
Narration of the past is always an ideological act: in a historical narrative temporal continuity and a causal relationship can be produced between fragmented and even unrelated events and phenomena. Narration is thereby a process of selecting meaningful elements and ordering them into a story that tells the plot in a particular way (Bal, 2009: 5). In the process of ordering the elements of the story, the complexity of the historical events is inevitably simplified and certain events are prioritized (Lähdesmäki 2017). Both history and myths are told from the standpoint of the past. However, only when the past is mobilized to create exclusive distinctions and to uphold views opposing 'us' and 'them', does the narrative tend to turn into myth, as Bottici and Challand (2014: 168) note. They define myth as 'a process of elaboration that takes place around a narrative core and that must respond to a need for significance' (Bottici and Challand 2014: 92).

In this article, I understand myths as narrative social practices that bestow significance to the experiences and deeds of their creators and mediators and whose power relies on a simplifying process. Indeed, mythmaking and transmitting of myths are acts of power. Following Barthes' views, I underline that myths seek to naturalize certain ideas and beliefs by hiding their historical origin and political motives. Because myths are narrated and presented as truths, they are difficult to rebut or object to (Barthes, 1993; Fiske, 1990). Even though Barthes' idea on naturalization of ideology is commonly referred to in recent studies on political myths, scholars have scarcely utilized in their analysis Barthes' semiotic views on the structure of a myth. Barthes (1993) calls myths a second-order semiological system, as it is constructed in a semiological chain. Myths are created by utilizing signs that already exist in culture: signs are used as signifiers to which new meanings are added. Myths fill signs with new meanings that are relevant to the political and ideological intentions of those creating them. In this article, myth is approached as a second-order semiological system and therefore the analysis of the 
discursive practice seeks to deconstruct the founding myths of EU Europe to their first-order signs in order to reveal the constructedness of myths and the workings of power in constructing them.

\section{Founding myths of EU Europe}

\section{Common origin and continuity}

A myth circulates stories and retells them in different temporal, cultural, and narrative contexts. While old myths are transmitted and transformed in narrative processes, new myths are constantly created and established. Probst (2003: 46) has divided the structure of myths into archaic and modern political myths. In his view, the structure of archaic myths emphasizes the religious or cultural origins of a community and a linear perception of the past. In the data, one of the key storylines of the foundation of EU Europe relies on the temporal structure of archaic myths. This founding myth emphasizes the idea of a common cultural origin of Europeans and EU Europe's historical continuity from the past; the current EU Europe is explained as being based on historical incidents and cultural phenomena reaching far back into the past and values narrated as shared and originating from a common European history. Although this myth emphasizes the historical origins of EU Europe, the motive to tell it is in the present, or even in the future.

The founding myth based on historical continuity commonly locates the origin of EU Europe in incidents dating back to antiquity, Roman times, the Middle Ages, the Renaissance, the Baroque or/and the Enlightenment and the values and virtues explained as originating from 
those times. The recurring elements in the narration of this myth are to underline the utmost importance of these incidents in the history of Europe, to consider the incidents as manifestations and mediators of particular values described as European, and to define the incidents and values as a particular European legacy. The myth brings to the fore, in particular, intellectual culture and arts dating to the temporal periods mentioned above.

The founding myth based on continuity is particularly referrer to and created when arguing the selection of EHL sites. I have chosen from my analysis three extracts that indicate how this founding myth is typically narrated in the data. The extracts are quotations from the selection reports of sites awarded with the EHL in 2015 and 2016. I will next discuss how this myth is textually constructed by circulating certain words, phrases, expressions, modes of argumentation, narrative elements, and storylines identified in the discourse analytical reading of the data. The first extract argues the European significance of 'The Heart of Ancient Athens', awarded with the label in 2015:

The heart of Ancient Athens comprises nearly one hundred monuments of European Significance, such as the Acropolis hill, the Ancient and Roman agorae, Hadrian's library, the Pnyx hill, and the Kerameikos cemetery. They make up a rich historical landscape where events fundamental to the formation of essential aspects of European culture and identity took place, from the development of classical art and theatre, to democracy, equal rights, and science. These monuments witnessed the birth and upbringing of key figures in European history whose intellectual achievements made an indelible mark on the definition of European common values as expressed in a variety of areas ranging from political and legal thought (Pericles), art and architecture (Phidias), literature and drama (Aeschylus, Sophocles, Euripides), medicine and science (Hippocrates), historical writing and the construction memory (Herodotus, Thucydides), just to name a few. (EC, 2014: 6) 
The extract includes several expressions through which the fundamentality of the legacy of Ancient Athens for EU Europe is highlighted. The text brings to the fore events that are described as 'fundamental to the formation of essential aspects of European culture and identity' and intellectual achievements that have 'made an indelible mark' on 'European common values'. The extract emphasizes the cultural unity of Europe by referring to a singular 'European culture and identity', 'European history', and European values that are 'common'. It underlines the idea of persistency of tangible and intangible heritage and temporal continuity of both material objects — 'monuments' that have 'witnessed' the life of ancient Great Menand ideas that these material objects manifest. The origin of European culture and identity is narrated as stemming from intellectual achievements of numerous ancient 'Great Men', of which the text 'just [--] name[s] a few'.

The second extract argues the European significance of The Archive of the Crown of Aragon, awarded with the EHL in 2015. The extract demonstrates a recurring element in the narration of the founding myth of EU Europe in the data: the narration seeks to influence and impress by emphasizing the greatness of past incidents, achievements, and material objects. The story of the greatness of the site is told by using superlatives and expressions that indicate its exclusiveness and uniqueness:

The Archive of the Crown of Aragon, founded in 1318, is one of the oldest archival institutions in Europe and is considered to hold one of the largest and most valuable document collections of medieval Europe. It also possesses one of the oldest testimonies of the creation process of a European state and rule of law including its parliamentary system. The documents of parliamentary assemblies in its holdings can be regarded as the immediate antecedents of present day parliaments. (EC, 2014: 8) 
In the extract, the vocabulary of greatness is intertwined with the description of the construction of a European polity, as the archive is described as possessing 'one of the oldest testimonies of the creation process of a European state and rule of law including its parliamentary system'. The text emphasizes the continuity of parliamentarism as a system of governance in Europe, as the documents in the archive 'can be regarded as the immediate antecedents of present day parliaments'. The archive is narrated as testifying the origin of parlamentarism not only in Spain but broader in Europe. The narration in the extract places the roots of the EU's core political ideals, such as rule of law, far back in the past. In addition, selecting an archive as an official European heritage and highlighting the practices of retaining and transmitting 'old testimonies' to the present day brings to the fore the discourse of preservation that recurs in this founding myth of EU Europe.

The third extract from the EHL selection reports give reasons why a site known as Sacrum promontorium in Portugal was awarded with the EHL in 2016:

The site constitutes a rich cultural landscape that contains traces of the origins and development of European civilisation dating back to the megalithic period. It was known in Roman times as the Sacrum promontorium (sacred promontory), from where it derives its name-a status that continued into the early Middle Ages with the establishment of the Igreja do Corvo (Church of the Crows), which housed the shrine of St. Vincent, and became a popular place of pilgrimage for Iberian Christians. Having been chosen by Prince Henry the Navigator as the headquarters for his projects of maritime expansion it became the privileged scenario for the accomplishments of the Age of Discoveries in the fifteenth century, a key historical moment that marked the expansion of European culture, science, and commerce both towards the 
Atlantic and the Mediterranean, setting European civilization on its path to the global projection that came to define the modern world. (EC, 2015: 8)

In this extract, 'the origins and development of European civilization' reach back to the megalithic period. The narration emphasizes the idea of continuity by bringing out the continuing importance of the site through Roman times, the Middle Ages, and the Age of Discoveries culminating in a global expansion of 'European culture' and 'European civilization'. The narration in the extract represents European civilization as a master of the modern world.

The founding myth that emphasizes EU Europe's historical continuity is thus a success story. Through the emphasis on the historical continuity of European culture, civilization, and polity and the dignity of virtues and values transmitted from the past to the present, this founding myth includes a highly positive ethos. Its power relies on its moral and ethical righteousness: it would be morally and ethically unjustifiable to downplay the legacy of the past or deny the importance of the social and societal virtues and values, such as peace, democracy, justice, equal rights, and rule of law, repeated in the narration of the myth-as well as in EU policy rhetoric in general.

Destruction, temporal break, and rebirth

As an opposite to archaic myths, Probst (2003: 46) describes the structure of modern political myths as being based on discontinuity. According to him, modern political myths emphasize interruption of the past and the emergence of a new beginning initiated by the collective action 
of people. Modern political myths rely on revolutionary breaks that have led or will lead to new agreements about the ethical foundation of the community (Probst, 2003: 46). Besides the founding myth emphasizing historical continuity, the data also include storylines that stem from a break with the past. In this founding myth, EU Europe rises like a phoenix from the ashes of the total destruction of WWII. Totalitarianisms, the death of millions of people, and ruined cities in Europe are narrated in this founding myth as a turning point in history and as the root cause and initial impetus to the development of the EU. Although the starting point of this myth is negative with its emphasis on extreme agony, violence, hatred, oppression, and injustice, the myth turns the legacy of this turning point into a positive ethos of conquering these negative extremes and promoting their positive opposites: peace, freedom, justice, and solidarity.

Kelsey (2014) and Lule (2001) have discussed the role of scapegoats in storytelling and contemporary mythmaking. As myths protect and proclaim the core values and central beliefs of a community, scapegoats embody and display characteristics of evil or guilt that stand in contradiction to the moral codes of the community (Kelsey, 2014: 310; Lule, 2001: 23). A community needs scapegoats to foster and share its values among its members. The founding myth of EU Europe is told by scapegoating 'the national' for causing the total break in the temporal continuity of the continent. In the myth, the idea of a break, scapegoating 'the national', seeking 'a fresh start', and the European integration process form a closely connected set of meanings.

I have chosen from my analysis three extracts that demonstrate typical elements in textual narration of the founding myth based on a temporal break. The first extract is an audio 
introduction for the 'Beginnings' hall available through portable media guides at the first information table:

For decades, the stage of Europe progressed under the same principle: Each nation for itself. Countries fought to secure their own interests with force, if necessary. The dreadful consequences of this approach were the two World Wars. By the end of the Second World War the continent is in ruins with widespread mistrust and increasing desperation. Yet for one group of prominent and forward-looking politicians the solution is clear: the ideas of the past must be discarded. Despite the new major threat looming — the Cold War between the USA and the Soviet Union - they dare to make a fresh start. In their vision, those in charge will stop pointing weapons at one another and instead take their seats around the same table in the name of consensus and cooperation, thus paving the way for a peaceful and prosperous Europe. This vision brought about the first decisive steps toward the Schumann declaration. At this table you will discover just how this document of utmost importance for Europe's future came to be and how the world reacted.

In the extract, the scapegoat for a European post-war predicament-where 'the continent is in ruins with widespread mistrust and increasing desperation'-is the selfishness of European nations as 'countries fought to secure their own interests'. The idea of a temporal break is narrated in the text by referring to 'a fresh start' that the 'prominent and forward-looking politicians' 'dare[d]' to make. A fresh start required that the 'ideas of the past must be discarded'. Discarding national interests is narrated in the extract as 'paving the way for a peaceful and prosperous Europe'. The beginning of EU Europe is located in the break and 'the first decisive steps' in the construction of the European economic and political community. The temporal orientation in this myth is not, however, only in the time of the break. As the extract indicates, the myth simultaneously deals with 'Europe's future'. As the extract 
demonstrates, the founding myth based on the idea of a temporal break also utilizes expressions of 'greatness' in its description of the roots of the European integration process.

The timing of the temporal break in the founding myth of EU Europe is flexible and varies in the narration of the myth. The major break is commonly dated to WWII, but the idea of a break also reaches in the narration of the myth to the struggle against communist regimes in Central and Eastern European countries after WWII. The next extract is from the EHL selection report that argues the European significance of the Historic Gdańsk Shipyard, awarded with the EHL in 2015 .

The Historic Gdańsk Shipyard has strong associations to the birth and commemoration of the Solidarity movement and to the origins of democratic transformations in Central and Eastern Europe in the late 20th century. The events that started in August 1980 at the Vladimir Lenin Shipyard in Gdańsk had a fundamental influence on the recovery of freedom by Poland and by other Central and Eastern European countries ruled by communist regimes. These events paved the way to the end of the Cold War and to changes in post-Yalta Europe and the world. [--] The Historic Gdańsk Shipyard already has a rich programme of activities to communicate its European significance and the role played by the Solidarity social movement in the development of freedom, justice, democracy and human rights in Poland and in other Central and Eastern European countries ruled under communist regimes. (EC, 2014: 20)

In the extract, the Historic Gdańsk Shipyard is identified as a place of 'the birth' and of 'the origins' of a core democratic movement objecting to a communist regime. The idea of a break is dated in the extract to the 'end of the Cold War and to changes in post-Yalta Europe and the world'. The narration connects the break and the new beginning to the development of various 
values - 'freedom, justice, democracy and human rights' — that are commonly repeated in EU policy rhetoric.

The founding myth of EU Europe that emphasizes a temporal break has an explicit ideological motive: it promotes the necessity of the EU and the EU institutions for creating and maintaining societal values, such as peace and prosperity, in Europe. The third short extract crystallizes this motive:

Bilingual Strasbourg has a symbolic location in the centre of Europe. After the Second World War, European institutions created for maintaining peace were housed in an area which became the European district of Strasbourg. These institutions are the drivers of European consolidation; they are central to the strengthening of human rights and to the defence of democratic values and the rule of law. (EC, 2015: 14)

The extract is from the EHL selection report that argues why the EU administrative buildings in Strasbourg were awarded with the EHL in 2016. The break-WWII-is dated in the extract as the starting point for EU Europe. The 'European institutions' and the European integration process-'European consolidation' - are narrated in the text as 'central' to the values, such as 'human rights', 'democra[cy]', and 'the rule of law', whose importance is undeniable in the myth.

Founding fathers and heroes as temporal mediators

In addition to the founding myths emphasizing continuity and a temporal break, the data include a third storyline that functions as a mediator between these two mythical narratives. 
Both the EHL documents and the exhibition in Parlamentarium bring up several persons that are presented as founding figures or key heroes in the story of EU Europe. These heroes and their heroic achievements are narrated in the data as transmitting to the present the values and legacy of the past and guiding the development of EU Europe through the temporal break.

Although not all myths need heroes, hero figures are their typical elements. A broad body of scholarly literature on hero myths have explored their origin and explained their meanings from diverse perspectives. The psychological perpectives emphasize the need for heroes as a fundamental part of the human condition (Kavanagh and O'Leary, 2004). Hero myths have been argued to dramatize the struggles faced by people and to provide a cognitive schema that map one's psychological progress through life (Bartunek, 1984). When this kind of 'need' for a hero has been explored from a cultural perspective, several scholars have noted the similarity and repeated patterns between hero myths in different cultures and historical time periods. Thus, hero myths have been considered timeless and multicultural (Saxby, 1979) and as monomyths (Campbell, 1949), since tales of heroic deeds contain recurring themes and moral lessons that are told in various cultural and narrative contexts and have endured through the ages (Lule, 2001; Whelan and O'Gorman, 2007) Even though hero myths have been perceived to follow a similar pattern, the hero figures do not carry a monolithic form or a set of characteristics and values. Indeed, hero figures are personified and dramatized to reflect the core values and ideals of the society in which their stories take place (Lule 2001: 82). Several scholars have described recurring elements in hero myths (e.g., Jung, 1981; Campbell, 1949; Lule, 2001) and crystallized their narrative structure to a few core phases. In myths, the hero figure commonly has a humble or obscure background, the hero initiates a quest, needs to leave the group or embark on a journey, overcomes adversity, setbacks, and temporary failures, faces 
battles and trials and takes on a formidable enemy, and finally returns to popular acclaim and is honored for his/her accomplishments (Lule, 2001: 82; Whelan and O'Gorman, 2007: 85).

The texts in the data bring to the fore the so-called Founding Fathers of the EU and narrate their story by following the narrative structure and phases of hero myths. In the data, Jean Monnet, Robert Schuman, Alcide de Gasperi, Konrad Adenauer, and Joseph Bech are explicitly named as Founding Fathers of the EU, but the narrative mythmaking focuses particularly on Robert Schuman. His story as a key Founding Father is told in Parlamentarium through the portable media guide in the beginning of the 'Beginnings' hall. This $13^{1 / 2-m i n u t e}$ story is titled 'Story of the Origin' and it narrates the founding myth of EU Europe from the point of view of agency. I have chosen from my data this story as an example of hero mythmaking, as this story is in a central position in the exhibition of Parlamentarium.

The story briefly introduces the background of its hero, Robert Schuman. His past is presented in the context of the conflicted history of Europe. It is told that he grew up in the Rein, 'the scene of much conflict between France and Germany', that he was 'familiar with both countries', and was 'educated in both French and German' while having Luxemburgish as his mother tongue. The narration of a hero myth activates when the key figures in the story, Jean Monnet and Robert Schuman, initiate a quest: 'a permanent solution for the old political and economic conflicts between France and Germany must be found.' Jean Monnet has a core role as a 'mentor' and a 'helper', in Campbell's terms, in the narrative structure of the hero myth: 'He knows that reconciliation between France and Germany could only be initiated with backing at the highest levels. Monnet's search for political support leads him to the French Foreign Minister, Robert Schuman, who he convinces to join to him.' When Schuman decides to cross the threshold of the (metaphoric) hero journey, in Campbell's terms, he has to leave 
his own 'group', the French Parliament, in terms of loyalty, and conduct his dangerous mission in secret, as the story tells:

Monnet and Schuman developed the initial plan for economic cooperation in a field of coal and steel between France, Germany, and their European neighbors under the joint control of one supranational organization. Supported by experts and advisers, they were meticulous about the wording, and over several weeks composed eight drafts before the final version of the declaration. This is all kept secret from France's politicians, a slightest leak could endanger, even end their plans.

The narrative elements of the story emphasize its adventurous nature and truthfulness. Its core moments are told by using the so-called historical present tense and references to exact details in the course of events and their timing. The authenticity of the events is emphasized by quoting the words of the hero. In the story, the struggle that the hero has faced in conducting his heroic deeds is rewarded with success - he has created a declaration of utmost political importance and 'clear[ed] the first hurdle' in his 'journey':

The 9th of May, 1950. Nine am. The final version of the declaration is complete. Still only Robert Schuman, Jean Monnet, and the select group of staff of foreign politicians know of its existence. Ten am. The council of ministers of the French government summon the meeting. Shortly before Robert Schuman speaks the text is distributed amongst the cabinet members in attendance. The condition for the joining together of European nations is ending the centuries old conflict between French and Germany. 'Europe will be born from this. A Europe which is solidly united and constructed around a strong framework.' [--] Schuman reads out just a few central passages from the declaration and asks for consensus. No one had expected a paper with such explosiveness and political importance. [--] The French government agrees to follow the recommendation and thus endorses it, clearing the first hurdle. 
The hero in the story has succeeded in ending 'the centuries old conflict' and giving birth to a 'solidly united' Europe. But in the story, more challenging struggles are still to come:

In Germany and France, emotions run higher. Some politicians are reluctant to hand over power to a supranational organization. Industry leaders fear the loss of customs borders and the threat unleashed by opening up their market to competition. Unions see their influence shrinking and are aware of the dominance of the private sector that will curb workers' rights.

However, the hero succeeds in conquering also the latter struggles, even 'the Soviet Union's clear and emphatic objections'. At the end of the story, 'Schumann declaration is widely accepted at the national, European, and global political levels'. Finally, the hero gets his popular acclaim as '[t]he 9th of May goes down in history and is celebrated to this day as Europe day'.

\section{A thick or thin European identity?}

The founding myths emphasizing historical continuity and a temporal break narrate the story of EU Europe from two distinct angles. While the first emphasizes shared cultural roots and preservation and transmission of a common legacy, the latter is based on the idea of a rebirth and development of a civic/political community. While the first founding myth can be perceived as high-cultural, intellectual, even elitist, and thus exclusive, the latter can be described as less-cultural, emotional, political, and seeking to be more inclusive. 
Although all three mythical storylines explored in the previous section can be found in both the EHL selection reports and the permanent exhibition in Parlamentarium, the analysis indicates that the European Commission and the European Parliament have slightly different emphases in their attempts to create the constitutive story of EU Europe. While the Commission's constitutive story emphasizes the first founding myth, the Parliament's story commonly stresses the second one. The differences follow the administrative ethos of these EU bodies. In general, the Commission seeks to represent Europe as a whole, while the Parliament is based on cooperation between the representatives of the separate European member-states. It is more 'natural' for the Commission to bring to the fore a myth that relies on the idea of continuity and European unity that has its origin far back in time. The idea of a break as the basis of a common origin fits the ethos of the Parliament better: the more recent political unity in Europe is more easily adapted to the diversity of national histories.

Myths are stories that remind us who we are collectively and individually (Lule, 2001; O'Donnel, 2003). Thus, myths have a central role in identity building. Indeed, the EU's interest in the creation and promotion of the founding myths of EU Europe stems from the identity and integration politics of the EU. The EU history and heritage initiatives seek to impact Europeans by connecting political and ideological rhetoric and the narrative elements and structure of myths. The key political mission of these initiatives is to foster a feeling of belonging to Europe and the EU and to establish a common European identity. The founding myths seek to produce a European identity from two distinct stands. While the first myth frames a European identity as a 'thick' cultural identity, the second approaches it as a 'thinner' political identity (on the concepts, see, e.g., Delanty, 2003; Davidson, 2008). The mythical hero figures participate in the construction of both identity modes. 
One of the hegemonic modes of narrating the past and a group identity relies on national history writing. National histories and their storylines have had and still have a crucial role in structuring the understanding of the communal past and present. Therefore, various myth scholars have been interested in the production of national myths in diverse nation-building processes. The mythological dynamics of a nation requires a denial of differences within it and a bypassing of other possible identifications of the members of the nation. Even though national identity is fundamentally multi-dimensional and cannot be reduced to a single element, the simplicity of a myth enables reducing national identity to somewhat monolithic accounts of culture, race, or religion that inevitable include multiple social forms (Kelsey, 2015). The narration of the nation has produced and established various mythical stories of the past, crucial moments, and heroes of the nation and thus naturalized the idea of the nation as the core unit of history and communal ideological consciousness.

Due to the hegemony of 'the national', scholars (Larkham, 1994: 270; Ashworth and Larkham, 1994: 8-9; Shore, 2000: 225) have asked whether it is possible to create a European identity and conception of culture that could substitute heroes, villains, battles, and revolts that are common in most national founding myths and mythologies. However, scholars have also noted that the scholarly discussion on identity building within the EU has often focused on identity building practices imitating those of the nation-states (Petersson and Hellström, 2003: 236), and therefore they have criticized the use of the national template as a normative model for understanding the formation of a European identity (Sassatelli, 2009: 74). The elements recurring in national myths and mythologies are, however, also utilized in the EU's attempts to narrate the story of EU Europe. The same elements recur in both stories because they rely on the same deep cultural codes, semiotic orders, and narrative practices that function as a mainstay of myth. 
The EU's heritage and history initiatives offer a good-but in its current state a rather underdeveloped - arena for responding to various transnational challenges in today's Europe and for creating inclusive narratives of being European and belonging to Europe. The initiatives could deconstruct various 'grand narratives', such as that of nationalism, which include exclusive or even discriminative ethos towards diverse 'others'. To utilize better the opportunities included in these initiatives, European policy discourse could benefit from a notion of a European heritage that Delanty $(2010 ; 2017 \mathrm{a} ; 2017 \mathrm{~b})$ has described as 'cosmopolitan' and 'transnational'. Instead of searching for a common layer of meanings, a European heritage is perceived in this approach in terms of several competing histories and memories, a plurality of interconnecting narratives, and the inclusion of new voices, such as those of post-migration communities, that forge a European heritage in new spaces of critical dialogue (Delanty 2017b: 3).

\section{Conclusion: Myths and the workings of power}

The analysis of the data brought to the fore three storylines through which the constitutive story of EU Europe is narrated in the selected EU initiatives. These founding myths are constructed from familiar narrative elements-signs commonly used in the narration of national histories, popular history, and Western art and cultural history—which are reused and filled with new meanings. In their new use, these signs create for the EU a history that reaches far back in time and a cultural, mental, and political legacy that is presented as crucial to be preserved, fostered, and transmitted to the future. 
Following Barthes's (1993) model of semiosis, the founding myths of EU Europe link signs as new 'signifiers' with various social myths and ideologies as their 'signified' contents. While, the first founding myth utilizes the signs of civilization and intellectualism by linking to them the ideas of Europeanness and the EU as their protector, the second myth uses the imagery and narratives of war and political conflicts familiar from national histories and connects them to the idea of a common European turning point from which Europe can survive only through unification and objection to 'the national'. The hero myth utilizes the Great Men recognized in national and political history by connecting to them narrations of European unification and integration. As a result of these semiotic processes, new myths occur that narrate a constitutive story of EU Europe that makes a claim about the legitimacy of the EU.

The founding myths of EU Europe emphasize specific ideological stands and moral codes. The myths bring forth social and societal values_-such as peace, democracy, justice, rule of law, human rights, tolerance, and solidarity—and narrates them as European. These values belong to a recurring vocabulary of the EU policy discourse that is repeated on all policy levels from EU treaties to single decisions. The myth of the Founding Fathers and other visionary heroes of EU Europe emphasizes, in particular, the ethics of deeds for 'greater' purposes, the greatness of the attempts of struggling for the community, and the gratitude for such endeavors. In general, the three founding myths promote the traditional European conception of patrimoine - the idea that the present has a particular duty to the past and its material traces in passing their inheritance to future generations (Smith, 2006; Choay, 2001). In addition, the myths emphasize in their approach to the past the ideas of civilization and cultivation of people about a common heritage — and, thus, bring forth a conception of heritage that has its roots in the mindset of Enlightenment. Indeed, since the 18th century heritage has been perceived as a tool for educating the society at large about the values and virtues narrated as stemming from 
the past and its remnants (Gillman, 2006). The founding myths of EU Europe are about education: they seek to cultivate people about the past in general—but also to educate them to be 'Europeans' and 'EU citizens' in particular.

Mythmaking is about the use of power. In a formative moment, mythmaking becomes particularly powerful. The founding myths of EU Europe promote the views of those in power in the EU. These myths seek to naturalize the idea of a shared European past, common cultural roots, a European identity, and continuity of certain European virtues and values from the past to the present. The founding myths justify the political aims of the EU, i.e., strengthening European unification and multilevel integration, and present these aims as choiceless and morally and ethically legitimated.

\section{References}

Ashworth, G.J. and Larkham, P.J. (1994) 'A Heritage for Europe: The Need, the Task, the Contribution in Building a New Heritage', in G.J. Ashworth and P.J. Larkham (eds) Tourism, Culture and Identity in the New Europe, pp. 1-9. London: Routledge.

Bal, M. (2009) Narratology: Introduction to the Theory of Narrative. Toronto: University of Toronto Press.

Barthes, R. (1993) Mythologies. London: Vintage. 
Bartunek, J.M. (1984) 'Changing Interpretative Schema and Organizational Restructuring', Administrative Sciences Quarterly 29: 355-372.

Bell, D. (2003) 'Mythscapes: Memory, Mythology, and National Identity', The British Journal of Sociology 54(1): 63-81.

Bottici, C. (2007) A Philosophy of Political Myth. Cambridge: Cambridge University Press.

Bottici, C. and Challand, B. (2014) Imagining Europe: Myth, Memory, and Identity. Cambridge: Cambridge University Press.

Browning, C.S. (2008) Constructivism, Narrative and Foreign Policy Analysis: A Case Study of Finland. Bern: Peter Lang.

Campbell, J. (1949) The Hero with a Thousand Faces. London: Fontana.

Campbell, D. (1992) Writing Security: United States Foreign Policy and the Politics of Identity. Manchester: Manchester University Press.

Choay, F. (2001) The Invention of the Historic Monument. Cambridge: Cambridge University Press.

Davidson, A.C. (2008) 'Through Thick and Thin: "European Identification” for a Justified and Legitimate European Union', Journal of Contemporary European Research 4(1): 32-47. 
Delanty, G. (2003) 'Is There a European Identity?' Global Dialogue 5(3-4).

Delanty, G. (2010) 'The European Heritage from a Critical Cosmopolitan Perspective', LSE 'Europe in Question' Discussion Paper Series 19: 1-20.

Delanty, G. (2017a) 'Entangled Memories: How to Study Europe's Cultural Heritage', The European Legacy 22(2): 129-145.

Delanty, G. (2017b) The European Heritage. A Critical Re-Interpretation. London: Routledge.

EC (2014) European Heritage Label. 2014 Panel Report. Brussels: European Commission.

EC (2015) European Heritage Label. 2015 Panel Report. Brussels: European Commission.

EP (2016) The European Parliament's Visitors' Centre. Visitor's Guide. Brussels: European Parliament.

EP and CoEU (2011) 'Decision No 1194/2011/EU of the European Parliament and of the Council of 16 November 2011 establishing a European Union action for the European Heritage Label', Official Journal of the European Union L 303: 1-9.

Fairclough, N. (1992) Discourse and Social Change. Cambridge: Polity Press.

Fairclough, N. (1995) Critical Discourse Analysis: The Critical Study of Language. London: Longman. 
Fiske, J. (1990) Introduction to Communication Studies. London: Routledge.

Flood, C. (2002) Political Myth: A Theoretical Introduction. London: Routledge.

Gillman, D. (2006) The Idea of Culture Heritage. Cambridge: Cambridge University Press.

Horelt, M.-A. and Renner, J. (2008) 'Denting a Heroic Picture: A narrative Analysis of Collective Memory in Post-War Croatia, Perspectives 16(2): 5-27.

Jung, C.G. (1981) The Archetypes and the Collective Unconscious, Collected Works. Princeton: NJ: Bollingen.

Kaasik-Krogerus, S. (2016) Normative Stories of the Formative Moment. Construction of Estonian National Identity in Postimees During the EU Accession Process. Helsinki: University of Helsinki.

Kelsey, D. (2011) 'Mentioning the War: A Critical Discourse Analysis of the "Blitz Spirit" in British Newspaper Responses to the July 7th Bombings', in B. Baybars-Hawks and L. Baruh (eds) Societies Under Siege: Media, Governance, Politics and Citizens Freedoms in an Age of Terrorism, pp. 50-65. Newcastle: Cambridge Scholars Publishing.

Kelsey, D. (2012) 'Remembering to Forget: Supporting and Opposing the War on Terror through the Myth of the Blitz Spirit after the July 7th Bombings', Critical Approaches to Discourse Analysis across Disciplines 6(1): 23-37. 
Kelsey, D. (2014) 'The Myth of the City Trickster: Storytelling, Bankers and Ideology in the Mail Online', Journal of Political Ideologies 19(3): 307-330.

Kelsey, D. (2015) 'The Myth of the "Blitz Spirit" in British Newspaper Responses to the July 7th Bombings', in B. Baybars-Hawks and L. Baruh (eds) If It Was Not for Terrorism: Crisis, Compromise, and Elite Discourse in the Age of "War on Terror", pp. 50-64. Newcastle: Cambridge Scholars Publishing.

Kelsey, D. (2016) 'Hero Mythology and Right-Wing Populism. A Discourse-Mythological Case Study of Nigel Farage in the Mail Online', Journalism Studies 17(8): 971-988.

Kavanagh, D. and O'Leary, M. (2004) 'The Legend of Cu Chulainn: Exploring Organization Theory's Heroic Odyssey', in Y. Gabriel (ed.) Myths, Stories, and Organizations: Premodern Stories for Our Times, pp. 116-130. Oxford: Oxford University Press.

Lähdesmäki, T. (2016) 'Comparing Notions on European Cultural Heritage in EU Policy Discourse and Scholarly Discussion', The International Journal of Interdisciplinary Social Studies: Annual Review 11: 1-14.

Lähdesmäki, T. (2017) 'Narrativity and Intertextuality in the Making of a Shared European Memory', Journal of Contemporary European Studies 25(1): 57-72. 
Larkham, P.J. (1994) 'A New Heritage for a New Europe: Problem and Potential', in G.J. Ashworth and P.J. Larkham (eds) Building a New Heritage. Tourism, Culture and Identity in the New Europe, pp. 260-273. London, Routledge.

Leach, E. (1970) Lévi-Strauss. London: Fontana.

Littoz-Monnet, A. (2012) The EU Politics of Remembrance: Can Europeans Remember Together? West European Politics 35(5): 1182-1202.

Lule, J. (2001) Daily News, Eternal Stories: The Mythological Role of Journalism. New York: Guilford Press.

Mi-Kyung, K. and Robertson, J.D. (2002) 'Analysing German Unification: State, Nation and the Quest for Political Community', German Politics 11(3): 3-18.

O'Donnell, M. (2003) 'Preposterous Trickster: Myth, News, the Law and John Marsden', Media Arts Law Review 8(4): 282-305.

Petersson, B. and Hellström, A. (2003) 'The Return of the Kings. Temporality in the Construction of EU Identity', European Societies 5(3): 235-252.

Phillips, A. (2011) Good Writing for Journalists: Narrative, Style, Structure. London: Sage.

Probst, L. (2003) 'Founding Myths in Europe and the Role of the Holocaust', New German Critique 90: 45-58. 
Prutsch, M.J. (2013) European Historical Memory: Policies, Challenges and Perspectives. Directorate-General for Internal Policies. Brussels: European Parliament.

Ringmar, E. (1996) Identity, Interest and Action. A Cultural Explanation of Sweden's Intervention in the Thirty Yeas's War. Cambridge: Cambridge University Press.

Sassatelli, M. (2009) Becoming Europeans. Cultural Identity and Cultural Policies. New York: Palgrave Macmillan.

Saxby, M. (ed.) (1979) Through Folklore to Literature. Sydney: IBBY Australia Publications.

Scott, J.W. (2002) 'A Networked Space of Meaning? Spatial Politics as Geostrategies of European integration', Space and Polity 6(2): 147-167.

Shore, C. (2000) Building Europe: The Cultural Politics of European Integration. New York: Routledge.

Smith, L. (2006) Uses of Heritage. London: Routledge.

Whelan, G. and O'Gorman, C. (2007) 'The Schumpeterian and Universal Hero Myth in Stories of Irish Entrepreneurs', Irish Journal of Management 28(2): 79-107. 
Wodak, R. (2008) 'Introduction: Discourse Sstudies - Important Concepts and Terms', in R. Wodak and M. Krzyzanowski (eds) Qualitative Discourse Analysis in the Social Sciences, pp. 1-29. Basingstoke: Palgrave Macmillan.

Wodak, R. (2009) The Discourse of Politics in Action. Basingstoke: Palgrave Macmillan. 